\title{
Kappa-casein gene study with molecular markers in female buffaloes (Bubalus bubalis)
}

\author{
Antonio Roberto Otaviano ${ }^{1}$, Humberto Tonhati ${ }^{1}$, Janete Aparecida Desidério Sena ${ }^{2}$ \\ and Mario Fernando Cerón Muñoz ${ }^{3}$ \\ ${ }^{1}$ Universidade Estadual Paulista 'Júlio de Mesquita Filho', Faculdade de Ciências Agrárias e Veterinárias, \\ Departamento de Zootecnia, Jaboticabal, SP, Brazil. \\ ${ }^{2}$ Universidade Estadual Paulista 'Júlio de Mesquita Filho', Faculdade de Ciências Agrárias e Veterinárias, \\ Departamento de Biologia, Jaboticabal, SP, Brazil. \\ ${ }^{3}$ Universidad de Antioquia, Facultad de Ciencias Agrarias, Colombia.
}

\begin{abstract}
Caseins comprise make up about $80 \%$ of the total protein content of milk and present polymorphism with changes in the amino acid sequence. Within this abundance of proteins, kappa-casein is noteworthy, since it has been associated with differences in milk yield, composition and processing. The objective of this study was to observe the existence of polymorphism in the kappa-casein gene in female buffaloes. For this purpose, blood samples from 115 female buffaloes, collected with vacutainer by needle punctionure of the jugular vein, were used. for genomic DNA extraction was done from blood samples. The PCR-RFLP and SSCP techniques demonstrated that the studied animals were monomorphic for the kappa-casein gene. Only allele B was observed in these animals, which was present in homozygosis. Therefore, it was not possible to quantify the gene action on milk yield and its constituents. The monomorphism observed in the population studied would allow the development of a method to identify mixtures of cow and buffalo milk in mozzarella cheese production, especially because, in cattle, the kappa-casein gene is polymorphic.
\end{abstract}

Key words: buffaloes, polymorphism, PCR-RFLP, SSCP.

Received: March 11, 2004; Accepted: November 23, 2004.

\section{Introduction}

Milk is the characteristic secretion of the mammary glands of all mammals. Because of its function in nutrition of the young, it is necessarily complex; it must supply nutrients, minerals, and vitamins in proper form, kind, and amount. The composition of the milk of different species varies in the percentages of these constituents. All milks contain the same kinds of constituents, but in varying amounts. Within a given species, genetic factors and environmental conditions, such as the climate and the stage of lactation, influence the its composition. The constituents of milk are dispersed in an aqueaous solution; some, such as chlorides, sodium, and potassium, are in ionic dispersion; others, such as protein: lactose and part of the albumin, are in molecular dispersion; still others, such as casein and

Send correspondence to Antonio Roberto Otaviano. Universidade Estadual Paulista 'Júlio de Mesquita Filho', Colégio de Ciências Agrárias e Veterinárias, Departamento de Zootecnia, Via de Acesso Paulo Donato Castellane s/n, 14884-900 Jaboticabal, SP, Brazil. E-mail: aroctaviano@yahoo.com.br. phosphates, are in colloidal dispersion, the and fat is present as an emulsion (Henderson, 1971).

The polymorphism presented by milk proteins is due to the genetic variation, and their variants are transmitted by simple Mendelian inheritance with no dominance. Generally, they are detected by electrophoretic techniques, since amino acid substitutions or deletions modify the structure and/or electric charge of the molecules. However, certain heterogeneity can occur in caseins due to other processes, such as phosphorylation and glycolysation. According to McLean (1987), these are the so-called posttranscriptional variations.

The polymorphism of the milk casein gene has been associated to differences in milk composition, processing and quality (McLean, 1987) and also with to yield characteristics (Lin et al., 1986). In cattle, the kappa-casein gene (CSN3) presents two common genetic variants, $\mathrm{A}$ and $\mathrm{B}$, and these alleles differ by substitutions in 2 amino acids, at positions 136 and 148 (alanine) (Mercier et al., 1973). The variant CSN3 B is associated with processing properties, such as cheese making (Lin et al., 1992; McLean, 1987). In 
many countries, an increase in frequency and a superiority of allele CSN3 B was observed, when the progeny tested demonstrated a greater frequency of genotype $C S N 3 \mathrm{BB}$ in cattle. The genotypes $\mathrm{BB}$ and $\mathrm{AB}$ are used in artificial insemination programs, to obtain a greater increase the frequency of these alleles in commercially interesting cattle populations. Some authors have identified CSN3 genotypes by RFLP using cDNA sequences (Rando Digregorio et al., 1988; Rogne et al., 1989) and by PCR-RFLP in Bos taurus (Denicourt et al., 1990; Pinder et al., 1991).

Cattle caseins genes comprehend a $200 \mathrm{~kb}$ fragment in of chromosome 6 , arranged in tandem in the following order: $\alpha$-s1, $\beta, \alpha$-s2 and $\kappa$ (Lien and Rogne, 1993). Specifically, the $\kappa$-casein gene comprehends a $13 \mathrm{~kb}$ sequence divided into 5 exons (Alexander et al., 1988). Once the cattle $\kappa$-casein gene was characterizationed of the (Alexander et al., 1988), several studies have been done, since based on the fact that variant $B$ is associated to a superior phenotype for milk quality characteristics, mostly cheese processing.

According to Mitra et al. (1998), who used for the first of time the PCR-RFLP technique with restriction enzymes Hind III, Hinf I and Taq I, this technique made it possible to detected polymorphism in alleles A and B of the kappa-casein gene (CSN3) in Sahiwal cattle (Bos indicus), and in Murrah, Nili-Ravi and Egyptian buffaloes (Bubalus bubalis). The PCR product produced a 379 bp DNA fragment. The enzymes Hind III and Taq I produced two fragments of allele B: 156 and 223 bp, and 123 and 256 bp, respectively. Digestion with Hinf I resulted in three fragments of 132, 156 and $91 \mathrm{bp}$, respectively, for allele A of gene CSN3, and two fragments of 288 and $91 \mathrm{bp}$, respectively, for allele $\mathrm{B}$ of gene $C S N 3$, with a frequency of 0.16 in (Bos taurus) cattle. In the Sahiwal breed, 39 animals were identified with genotype $C S N 3 \mathrm{AA}$, and the other 18 with genotype CSN3 AB. The genotype $\mathrm{BB}$, however, was not detected among the animals studied.

The molecular techniques applied to genetics in conjunction with animal breeding techniques could give yield greater genetic gain by determining the potential of an animal, even before it is expressed phenotypically. A genetic marker serves to relate favorably alleles for quantitative characteristics with information about the individual mode of action and their interaction of genes, helping on the to understanding of the quantitative variations and their practical use in animal husbandry. According to Haley (1995), DNA markers present two possible future applications in animal selection, the combination of the best alleles of two or more breeds, and the selection of the best alleles within a breed or lineage.

This study had as the objective to of observeing the occurrence of polymorphism in the kappa-casein gene of female buffaloes, looking for possible associations with economical characteristics, such as: milk yield, and the contents of protein, fat, lactose and total solids.

\section{Material and Methods}

One hundred and fifteen lactating buffaloes, from the Fazenda Santa Eliza, Dourado County, State of São Paulo, were used studied. The animals were Murrah breed and its crossbreds, maintained on Brachiaria brizantha, cv. Marandu and Panicum maximum, cv. Tanzania, pastures, and received as supplement citrus pulp, cotton seed or barley and mineralized salt. The females were milked twice a day, and data on milk constituents (fat, protein, lactose and total solids) were obtained from observation readings under infrared light, using a Bentley2000 equipment.

Blood samples were collected by needle punctionure of the left jugular vein, with using a 5-mL vacutainer, containing $7.5 \mathrm{mg}$ EDTA. The tubes were maintained at $-20^{\circ} \mathrm{C}$ until used for DNA extraction.

\section{DNA extraction}

Genomic DNA was extracted from leukocytes, according to the methodology described by Zadworny and Kuhnlein (1990), and modified by Miretti (1998), which consists onf the removal of erythrocytes by successive rinses in saline buffer, containing Nonidet P-40, and subsequent lysis of the leukocytes using SDS (sodium duodecylsulphate) and protein precipitation with solution $\mathrm{NACl}$ concentrate.

After sample thawing, $300 \mu \mathrm{L}$ blood aliquots were transferred to $1.5-\mathrm{mL}$ eppendorf tubes, $40 \mu \mathrm{L}$ Nonidet P-40 $(12.5 \%)$ was added to each sample, and the volume was completed to $(1.5 \mathrm{~mL})$ with TKM-1 buffer. The solution was homogenized by vortexing and centrifuged for $15 \mathrm{~min}$ at $1700 \mathrm{xg}$; the supernatant was discarded and the pellet resuspended in $600 \mu \mathrm{L}$ TKM-1. The volume of the tube was completed with TKM-1 buffer, shaken vigorously and then centrifuged for $10 \mathrm{~min}$ at $2700 \mathrm{x} \mathrm{g}$. The supernatant was discarded and the pellet resuspended in $600 \mu \mathrm{L}$ TKM- 2 and $50 \mu \mathrm{L}$ SDS $10 \%$ by gently shaking the tubes. Then the samples were incubated in a water bath at $55{ }^{\circ} \mathrm{C}$ for $1 \mathrm{~h}$, followed by addition of $200 \mu \mathrm{L} \mathrm{NaCl} 6 \mathrm{M}$ and homogenization of the mixture by vortexing. After centrifugation at $17000 \mathrm{x} \mathrm{g}$ for $20 \mathrm{~min}$ at $4{ }^{\circ} \mathrm{C}$, and transfer of the supernatant to an eppendorf tube containing $1 \mathrm{~mL}$ cold absolute ethanol, the DNA was precipitated by gently inverting the mixture. The DNA was transferred to an eppendorf tube containing $1 \mathrm{~mL}$ of $70 \%$ ethanol, mixed by inversion, and centrifuged at $17000 \mathrm{x} \mathrm{g}$, at $4{ }^{\circ} \mathrm{C}$ for $15 \mathrm{~min}$. The supernatant was discarded and the DNA samples were dried under vacuum. Subsequently, $200 \mu \mathrm{L}$ TE (10:1) buffer was added, and the samples incubated at $55^{\circ} \mathrm{C}$ for $16 \mathrm{~h}$ to dissolve the precipitated DNA, followed by storage at $4{ }^{\circ} \mathrm{C}$.

\section{PCR Reaction and DNA Amplification}

The primers used for amplification of the kappacasein gene fragments were those described by Mitra et al. (1998), with the following nucleotide sequence: K1 (5'- 
CACGTCACCCACACCCACATTTATC-3'), K2 (5'-TA ATTAGCCCATTTCGCCTTCT CTGT-3') and KY (5'CGTTGTCTTCTTTGATGTCTCC-3'). The primers were used in pairs such as $\mathrm{K} 1$ with $\mathrm{K} 2$ and $\mathrm{K} 1$ with $\mathrm{KY}$.

Amplification reactions were done in a final volume of $25 \mu \mathrm{L}$, containing $100 \mathrm{ng}$ DNA, $0.5 \mu \mathrm{M}$ of each primer, 1X PCR buffer [10 mM Tris- $\mathrm{HCl}$ (pH 9.0), $1.5 \mathrm{mM} \mathrm{MgCl}_{2}$ and $50 \mathrm{mM} \mathrm{KCl}$ ], $100 \mu \mathrm{M}$ dNTPs and $0.5 \mathrm{U}$ Taq polymerase. The reactions followed the sequence: $95{ }^{\circ} \mathrm{C}$ for $60 \mathrm{~s}$ (initial denaturation), and 30 cycles of the sequence: $95^{\circ} \mathrm{C}$ for $60 \mathrm{~s}, 56{ }^{\circ} \mathrm{C}$ for $60 \mathrm{~s}$ and $72{ }^{\circ} \mathrm{C}$ for $60 \mathrm{~s}$.

\section{RFLP (Restriction Fragment Length Polymorphism) technique}

After amplificationed gene fragments, they were subjected to digestion by restriction enzymes in a total volume of $20 \mu \mathrm{L}$ (for Hind II - $10 \mu \mathrm{L}$ reaction solution, $2 \mu \mathrm{L}$ enzyme buffer, $0.2 \mu \mathrm{L}$ enzyme, $7.8 \mu \mathrm{L} \mathrm{H}_{2} \mathrm{O}$; and for AluI $10 \mu \mathrm{L}$ reaction solution, $2 \mu \mathrm{L}$ enzyme buffer, $0.5 \mu \mathrm{L}$ enzyme and $7.5 \mu \mathrm{L} \mathrm{H}_{2} \mathrm{O}$ ) and placed in the a thermocycler at $37^{\circ} \mathrm{C}$ for $1 \mathrm{~h}$. After digestion, the fragments were subjected to electrophoresis in an (3.5\%) agarose gel, TBE $1 \mathrm{X}$ buffer (Tris-HCl $1 \mathrm{M} \mathrm{pH} \mathrm{7.4;} \mathrm{EDTA} 0.5 \mathrm{M} \mathrm{pH} 8.0$ and $10.8 \mathrm{~g}$ boric acid) with ethydium bromide, at $60 \mathrm{~V}$ for approximately $2.5 \mathrm{~h}$. Visualization of the bands was done under ultraviolet lighting and a picture was taken in a Gel-Doc equipment (Bio-Rad). Thus, if the DNA was had been restricted with the proper enzyme, the polymorphic locus could be observed by the size change of the DNA fragment.

\section{SSCP (Single Strand DNA Conformation Polymorphism) Analysis}

After electrophoresis of the amplification reactions in $1 \%$ agarose gel, a $3 \mu \mathrm{L}$ aliquot of each sample was diluted in $7 \mu \mathrm{L}$ SSCP buffer (95\% formamide, $20 \mathrm{mM}$ EDTA, $0.05 \%$ bromophenol blue, $0.05 \%$ xylene-cyanol). Subsequently, the samples were denatured at $95{ }^{\circ} \mathrm{C}$ for $10 \mathrm{~min}$ and incubated in ice for a similar time interval, and then subjected to electrophoresis in an acrylamide:bisacrylamide (49:1) gel, in non-denaturing conditions, using the mini-proteon II system from BioRad, according to Orita et al. (1989). For each PCR product analyzed, there was a of the running time and of the polyacrylamide gel concentration were standardizationed (15\% for K1-KY and K1-K2 products). The gels were prepared with enough acrylamide:bis (49:1) to reach the desired concentration, $600 \mu \mathrm{L}$ of $10 \%$ APS and $6 \mu \mathrm{L}$ TEMED and milli-Q water to complete $6 \mathrm{~mL}$.

DNA visualization in the polyacrylamide gel after electrophoresis was done by silver nitrate staining, according to Bassan et al (1991).

\section{Results and Discussion}

\section{Averages of milk yield and its constituents}

Total milk yield and yield at 305 days were $1561.94 \pm$ $404.39 \mathrm{~kg}$ and $1483.76 \pm 343.74 \mathrm{~kg}$, respectively. In the same presentation order, total protein production and protein production at 305 days were $66.93 \pm 17.26 \mathrm{~kg}$ and $63.03 \pm 13.79 \mathrm{~kg}$, and total fat production and fat production at 305 days were $113.04 \pm 31.12 \mathrm{~kg}$ and $104.71 \pm 23.20$ $\mathrm{kg}$, respectively.

The percentages of fat, protein, lactose, total solids, and somatic cells were estimated at $6.9 \pm 0.68 \%, 4.13 \pm$ $0.23 \%, 5.19 \pm 0.14 \%, 17.38 \pm 0.79 \%$ and $64.00 \pm 47.67 \%$, respectively.

\section{Blood collection and DNA extraction}

A $(3 \mathrm{~mL})$ blood samples were was collected from each animal, and $300 \mu \mathrm{L}$ aliquots were then used for DNA extraction according to the previously described methodology. After extraction, material the DNA was then submeitted to electrophoresis in $(0.8 \%)$ agarose gel, in order to achieve concentration and quality in each all DNA samples, which presented a concentrations varying of from 30 to $80 \eta \mathrm{g} / \mu \mathrm{L}$.

\section{PCR reaction and DNA amplification}

The primers described by Mitra et al. (1998), amplified two DNA fragments with sizes $400 \mathrm{bp}$ and $280 \mathrm{bp}$, corresponding to primers $\mathrm{K} 1 \mathrm{~K} 2$ and $\mathrm{K} 1 \mathrm{KY}$, respectively. These primers then yielded two fragments of the CSN3 gene, which were denominated CSN3 $\mathrm{K} 2$ and CSN3 KY. After the reaction was completed, the samples were quantified to visualize the amplified fragments.

\section{RFLP (Restriction Fragment Length Polymorphism) analysis}

Digestion of fragment CSN3 K2 by restriction endonucleases Alu I and Hind III generated two fragments of 280 and $120 \mathrm{bp}$, respectively. For fragment CSN3 KY, the above mentioned endonucleases also generated two fragments, however, these were of $180 \mathrm{bp}$ and $100 \mathrm{bp}$, respectively.

The results of the RFLP analysis for both endonucleases demonstrated the existence of one allele for each one of the endonucleases Alu I $(+)$ and Hind III $(+)$.

These results are similar to those found by Mitra et al. (1998), whose primer pair (K1 and K2) yielded a 400 bp fragment for gene CSN3. According to these authors, used the RFLP technique with endonucleases Hind III and Hinf I was to study animals of Murrah and Nili-Ravi breeds, which resulted in and found a monomorphic band, using the, which demonstrated the presence of allele CSN3 B. Jairam (1975), observed homozygosis BB in Sahiwal breed cattle for the same gene, with a frequency of 0.16 for allele CSN3. 
The kappa-casein gene also presents alleles $\mathrm{C}$ and $\mathrm{E}$ with a 0.1 frequency, which was reported by Erhardt (1989) in a study of German origin cattle; however, neither the results found in this study and nor those of Mitra et al. (1998), did not allowed the identification of either allele.

In cattle, Mitra et al. (1998) found alleles CSN3 A and B using restriction endonucleases Hind III, Taq I and Hinf I. A 379 bp fragment was digested by restriction endonucleases Hind III and Taq I, generating fragments of 156 and $223 \mathrm{bp}$, and 123 and $256 \mathrm{bp}$, respectively. The restriction with Hinf I generated fragments of 132, 156 and $91 \mathrm{bp}$, respectively, in the case of allele CSN3 A, and two fragments of 288 and 91, respectively, in the case of allele CSN3 B. In the Sahiwal breed, 39 animals had a CSN3 AA genotype, and the other 18 were of genotype CSN3 AB, while the genotype $\mathrm{BB}$ was not detected for in this breed.

\section{SSCP (Single Strand DNA Conformation Polymorphism) analysis}

The two fragments of the buffalo gene CSN3 (CSN3 $\mathrm{K} 2$ and $C S N 3 \mathrm{KY}$ ) were subjected to analysis by the SSCP technique, thus confirming that all the animals were homozygous, not presenting any polymorphisms. Therefore, (this finding showed the existence of only one allele for gene CSN3, with all the studied animals being homozygous for this gene.) Mitra et al. (1998), Mercier et al. (1998), Denicourt et al. (1990) and Pinder et al. (1991) studied the exon IV of gene CSN3 in Murrah, Nili-Ravi and Egytian buffaloes by the RFLP technique and obtained the same results found in this study.

This is the first report of an analysis of gene CSN3 by the SSCP technique; therefore, the results coincided when the animals were analyzed with those found by the RFLP technique, showing that these animals are monomorphic for the gene CSN3. The variant kappa-casein genotype found in these animals was BB, and its allele was $\mathrm{B}$. The variant genotype $\mathrm{BB}$ is responsible for greater yield in cheese making (McLean, 1987). Even though it is monomorphic, gene $C S N 3$ has no direct connection with gene expression linked to milk yield, but it directly affects the manufacturing process of dairy products, as reported by Schaar (1984).

Gerencsér et al. (2002) studied the cDNA sequence and the flanking 5 ' region of kappa-casein genes and reported that they did found not present considerable variations in the three ruminant species (bovine, goat and sheep) analyzed. The identification of DNA sequences implies transcriptional control of the gene, which will help in the investigation of gene expression, using gene transfer methods. In order to understand the expression and regulation of the kappa-casein gene, the above mentioned authors Gerencsér et al. (2002) compared six different promoters for the kappa-casein gene at the sequence level. The observation of a high conversion rate, the transcription factor linking the sites in all known kappa-casein 5' regulator re- gions, indicated strong interactions between these sites and the transcription factors which are responsible for gene regulation and expression.

With the techniques used in the present study (Single Strand Conformation Polymorphism and Restriction Fragment Length Polymorphism), since these techniques provide a quick and very reliable analysis, to analyze the animals, it was found that they were homozygous for the kappa-casein gene, that is, they possess only allele B, confirming previous literature data.

It is known that milk yield is a quantitative characteristic, and the animals studied had milk production varying from high to low. The kappa-casein gene could be affecting this characteristic in these animals, but, since they were all homozygous, this influence could not be measured.

This homozygosis did not allow to quantify the alleles present in the population or to make any inference about the influence of each allele on milk yield and its components, such as protein, fat, lactose, and total solids.

Since in buffaloes the kappa-casein gene is monomorphic, it can be used as a molecular marker to identify milk mixtures in cheese making processes, because in cattle and other species this same gene is polymorphic, allele A being more frequent in the majority of the bovine races.

\section{Conclusion}

The PCR technique amplified two fragments of the CSN3 gene, called CSN3 K2 and CSN3 KY, with 400 and $280 \mathrm{bp}$, respectively.

The results of the RFLP analysis showed two fragments of, respectively, 280 and 120 bp (for CSN3 K2) and two fragments of, respectively, 180 and $100 \mathrm{bp}$, corresponding to CSN3 KY after restriction with enzymes Alu I and Hind III, which is in agreement with the literature.

Analysis by SSCP allowed the visualization of only one allele for gene $C S N 3$, so all the individuals were considered homozygous, with genotype BB.

It was not possible to assess how much the buffalo kappa-casein gene affects milk yield and its components, since all animals studied were monomorphic for that gene, as determined by PCR-RFLP and SSCP.

\section{Acknowledgements}

This study was supported by FAPESP.

\section{References}

Alexander LJ, Stewart AJ, Machinlay AG, Kapelinskaya TV, Tkach TM and Gorodetsky SI (1998) Isolation and characterization of the bovine kappa-casein gene. Europe Journal Biochemical 178:395-401.

Bassan BJ, Anollés GCE and Gresshof PM (1991) Fast and sensitive silver staining of DNA in polyacrylamide gels. An Biochemical 196:80-3. 
Denicourt G, Ferreti L, Rognoni G and Sgaramella V (1990) Restriction fragment length polymorphism analysis of the k-casein locus in cattle. Animal Genetics 21:107-114.

Erhardt G (1989) Kappa-casein in bovine milk - Evidence of a further allele (k-Cn e) in different breeds. J Anim Breed Genet 106:225-231.

Gerencsér A, Barta E, Boa S, Kastanis P, Bösze Z, Bruce C and Whitela WA (2002) Comparative analysis on the structural features of the 5' flanking region of $\kappa$-casein genes from six different species. Genet Sel Evol 34:117-128.

Haley CS (1995) Livestock QTLs - Bringing home the bacon? Trends Genetics 11:488-492.

Henderson JL (1971) The Fluid-Milk Industry. 3rd edition. Editor AVI, London, pp 2:18-19.

Jairam BT (1975) Studies on milk protein polymorphism in relation to certain physico-chemical characteristics of milk in dairy animals. PhD Thesis, Punjab University, Chandigrh

Lien S and Rogne S (1993) Bovine casein haplotypes number, frequencies and applicability as genetic markers. Animal Genetics 24:373-376.

Lin CY, McAllister AJ, Ng-Kwai-Hang KF and Hayes JF (1986) Effects of milk protein loci on first lactation production in dairy cattle. Journal Dairy Science 69:704-712.

Lin CY, Sabour MP and Lee AJ (1992) Direct typing of milk proteins as an aid for genetic improvement of dairy bulls and cows: A review. Animal Breeding Abstract 60:1-10.

McLean DM (1987) Influence of milk protein variants on milk composition, yield and cheese making properties. Animal Genetics 18:100-102.
Mercier JC, Brignon G and Ribadeau-Dumas B (1973) Structure primaire de la caséine k-B bovine Séquence complète. Europe Journal Biochemical 35:222-235.

Mercier JC, Chobert JM and Addeo F (1998) Comparative study of the amino acid sequences of the caseinomacropeptides from seven species. FEBS Lett 72:208-214.

Miretti MM (1998) Variabilidade genética no lócus BoLADRB3.2 de bovinos nativos e exóticos. Dissertação Mestrado, Universidade de São Paulo, Ribeirão Preto.

Mitra A, Schlee P, Krause I, Blusch J, Werner T, Balakrishnan CR and Pirchner F (1998) Kappa-casein polymorphisms in Indian dairy cattle and buffalo: A new genetic variant in buffalo. Animal Biotechnology 9(2):81-7.

Orita MH, Iwahana H, Kanazawa H and Sekiya T (1989) Detection of polymorphism of human DNA by gel electrophoresis as single strand conformation polymorphism. Proc Natl Acad Sci 86:2766-70.

Pinder SJ, Perry BN, Skidmore CJ and Savva D (1991) Analysis of polymorphism in the bovine casein genes by use of the polymerase chain reaction. Animal Genetics 22:11-20.

Rando A, Digregorio P and Masina P (1988) Identification of bovine k-casein genotypes at the DNA level. Animal Genetics 19:51-54.

Rogne S, Lien S, Vegarud G, Steine T, Langsrud T and Alestrom P (1989) A method of k-casein genotyping of bulls. Animal Genetics 20:317-321.

Schaar J (1984) Effects of kappa-casein genetic variants and lactation number on the renneting properties of individual milks. Journal Dairy Research 51:397-406.

Zadworny D and Kuhlein U (1990) The identification of the kappa-casein genotype in Holstein dairy cattle using the polymerase chain reaction. Theor Appl Genetic 80:631-634.

Associate Editor: Pedro Franklin Barbosa 